\title{
Fix me a glitch
}

Citation for published version (APA):

Cotta, D. (2018). Fix me a glitch: an empirical investigation of glitch mitigation and inter-functional transactive memory systems in engineer-to-order manufacturing. [Doctoral Thesis, Maastricht University]. Datawyse / Universitaire Pers Maastricht. https://doi.org/10.26481/dis.20181025dc

\section{Document status and date:}

Published: 01/01/2018

DOI:

$10.26481 /$ dis.20181025dc

Document Version:

Publisher's PDF, also known as Version of record

\section{Please check the document version of this publication:}

- A submitted manuscript is the version of the article upon submission and before peer-review. There can be important differences between the submitted version and the official published version of record.

People interested in the research are advised to contact the author for the final version of the publication, or visit the DOI to the publisher's website.

- The final author version and the galley proof are versions of the publication after peer review.

- The final published version features the final layout of the paper including the volume, issue and page numbers.

Link to publication

\footnotetext{
General rights rights.

- You may freely distribute the URL identifying the publication in the public portal. please follow below link for the End User Agreement:

www.umlib.nl/taverne-license

Take down policy

If you believe that this document breaches copyright please contact us at:

repository@maastrichtuniversity.nl

providing details and we will investigate your claim.
}

Copyright and moral rights for the publications made accessible in the public portal are retained by the authors and/or other copyright owners and it is a condition of accessing publications that users recognise and abide by the legal requirements associated with these

- Users may download and print one copy of any publication from the public portal for the purpose of private study or research.

- You may not further distribute the material or use it for any profit-making activity or commercial gain

If the publication is distributed under the terms of Article $25 \mathrm{fa}$ of the Dutch Copyright Act, indicated by the "Taverne" license above, 


\section{Summary}

In a context of increasing technological complexity and interdependent supply chains, operational glitches are a pervasive reality of organizational life. An operational glitch happens when there is a deviation from the expected flow of materials and information and remedial actions become required. Even though operational glitches are recurrent in many industrial settings, their occurrence poses difficult managerial problems for firms. Empirical studies evidence that the occurrence of operational glitches is associated with negative outcomes, such as increased operating costs, decreased delivery reliability, reduced customer loyalty and diminished firm reputation. What is missing is an understanding of how operational glitches specifically affects manufacturers' external quality performance. Furthermore, extant literature offers little guidance on how firms can minimize the performance impact of operational glitches. In this dissertation, I contribute to the literature on operational glitches and glitch mitigation by investigating the development of transactive memory systems in the context of engineer-to-order manufacturing.

In the first manuscript, "Mitigating the Impact of Transactive Memory Systems on External Quality Failures", we examine the relationship between the frequency of operational glitches and the incidence of external quality failures. We find that firms that accept more customer change orders, that make more design errors and that experience more nonconformities during manufacturing have a higher incidence of external quality failures. This result indicates that manufacturers have a hard time shielding their external quality performance from the occurrence of different types of operational glitches. We also find that manufacturers that develop an inter-functional transactive memory system for glitch mitigation activities are better able to alleviate the negative relationship between operational glitches and external quality failures.

In the second manuscript, we look into factors that underlie the development of interfunctional glitch mitigation transactive memory systems by drawing on the MotivationOpportunity-Ability framework. On the one hand, we finds that organizational policies (role formalization, cooperation incentives and the use of project managers) positively influence the development of inter-functional glitch mitigation transactive memory systems. On the other, we show that certain individual characteristics of departmental heads also affect such development. In particular, we find that the extent to which Heads of manufacturing are networked across the firm and the extent to which they have had experience working in other departments of the firm are important determinants of the level of development of inter-functional glitch mitigation transactive memory systems. 